\title{
LITERATUR REVIEW : HUBUNGAN MODEL HEWAN COBA (FAKTOR JENIS KELAMIN DAN HORMON) PADA SENSITIVITAS INDUKSI STREPTOZOTOCIN SEBAGAI AGEN DIABETOGENIK
}

\author{
Literature Review: The Relationship Model Of Test Animal (Factors Of Gender And \\ Hormones) On The Sensitivity Of The Induction Of Streptozotocin As An Agent Of \\ Diabetogenic
}

\section{Egi Claudia Pratiwi \\ Elsa Trinovita ${ }^{2}$ \\ Agnes Immanuela Toemon $^{2}$}

*IMahasiswa Program Studi Pendidikan Dokter, Fakultas Palangka Raya, Universitas Palangka Raya, Palangka Raya, Kalimantan Tengah, Indonesia

2 Dosen Pengajar Program Studi Pendidikan Dokter, Fakultas Kedokteran Universitas Palangkaraya, Palangkaraya, Kalimantan Tengah, Indonesia.

*email:

egiclaudiapratiwi@gmail.com

Kata Kunci:

Streptozotocin Jenis Kelamin

Hormon

Diabetes melitus

\section{Keywords:}

Streptozotocin

Gender

Hormones

Diabetes melitus

\begin{abstract}
Abstrak
Diabetes melitus (DM) merupakan salah satu penyakit metabolik yang menjadi perhatian dunia dan mempunyai karakteristik hiperglikemik. Pengujian agen antidiabetes baik penemuan obat baru ataupun komponen antidiabetes telah dikembangkan dengan menggunakan hewan coba yang diinduksi dengan agen diabetogenik streptozotocin. Efek samping penggunaan streptozotocin dilaporkan lebih rendah dibandingkan aloksan. Sensitivitas induksi streptozotocin dipengaruhi oleh beberapa faktor seperti jenis kelamin dan hormon. Terdapat perbedaan hasil pada beberapa penelitian tentang hubungan sensitivitas induksi streptozotocin dengan jenis kelamin. Metode penelitian menggunakan Literatur review atau menggunakan pendekatan secara systematic review. Artikel dikumpulkan melalui mesin pencari seperti NCBI, Google Scholar dan ResearchGate dengan memasukan kata kunci. Berdasarkan hasil sintesis data tentang hubungan sensitivitas induksi streptozotocin dengan jenis kelamin hewan coba didapatkan 15 artikel berhubungan dan 3 artikel tidak berhubungan. Jenis kelamin memiliki hubungan dengan sensitivitas induksi streptozotocin melalui hormon yang dimiliknya yaitu estrogen, progesteron dan testosteron.
\end{abstract}

\begin{abstract}
Diabetes mellitus (DM) is a metabolic disease that global concern and characterized by hyperglycemia. Tests for antidiabetic agents, either discovering new drugs or antidiabetic components, have been developed using experimental animals induced with the diabetogenic agent streptozotocin. The side effects of streptozotocin were reported lower than alloxan. The sensitivity of streptozotocin induction can be relied on by several factors such as sex and hormones - the difference in results in several studies regarding the relationship between streptozotocin induction sensitivity with gender. The research method is a literature review by using a systematic approach. Articles are collected through search engines like NCBI, Google Scholar, and ResearchGate by entering keywords. Based on the results of data synthesis on the relationship between streptozotocin induction sensitivity and the sex of the experimental animal, it found that fifteen articles were related and three articles were not. Sex has a relationship with streptozotocin induction's sensitivity through the hormones estrogen, progesterone, and testosterone.
\end{abstract}

(C) year The Authors. Published by Institute for Research and Community Services Universitas Muhammadiyah Palangkaraya. This is Open Access article under the CC-BY-SA License (http://creativecommons.org/licenses/by-sa/4.0/). DOI: https://doi.org// 0.33084/jsm.vxix.xxx.

\section{PENDAHULUAN}

Diabetes melitus (DM) merupakan salah satu penyakit metabolik yang menjadi perhatian dunia. Menurut World Health Organization (WHO), Indonesia menempati posisi ke-4 di dunia sebagai negara dengan jumlah penderita diabetes melitus terbanyak setelah China, India dan Amerika Serikat (WHO, 2016). Penyakit metabolik dengan karakteristik hiperglikemia 
disebut diabetes melitus yang terjadi karena kelainan kerja insulin dan kelainan pengeluaran insulin, dapat juga karena kedua-duanya (Setiati et al.,2017). Pengujian agen antidiabetes baik penemuan obat baru ataupun komponen antidiabetes telah dikembangkan dengan menggunakan hewan coba. Model hewan coba diabetes mellitus dilakukan dengan melibatkan komponen kimia yang memiliki agen diabetogenik sehingga dapat menyebabkan penyakit diabetes melitus pada hewan coba. Streptozotocin dan aloksan, namun kini penggunaan aloksan sebagai agen diabetogenik jarang digunakan jika dibandingkan dengan streptozotocin karena tingkat keberhasilan aloksan tidak cukup menguntungkan dan memiliki efek samping berupa nefrotoksik dan hepatotoksik pada model hewan coba. Efek samping penggunaan streptozotocin dilaporkan lebih rendah dibandingkan aloksan, dimana efek toksik streptozotocin menjadi lebih ketat terhadap sel $\beta$ pankreas karena struktur kimia yang dimiliki oleh streptozotocin berupa gugus glukosa sehingga mempermudah masuknya streptozotocin ke sel $\beta$ pankreas (Husna et al.,2019). Faktor-faktor yang mempengaruhi sensitivitas pada variabel streptozotocin meliputi strain, dosis pemberian, jalur pemberian, persiapan hewan coba dan jenis kelamin hewan coba (Deeds et al., 20II).

Namun, pada literatur review ini hanya akan membahas faktor jenis kelamin dari model hewan coba yang mempengaruhi sensitivitas pada variabel streptozotocin. Tikus atau mencit jantan cenderung lebih rentan terhadap streptozotocin dibandingkan dengan tikus atau mencit betina (Deeds et.al.,20II). Pada penelitian yang dilakukan oleh Aseer et.al melaporkan bahwa saat peneliti menilai kadar gula darah yang diindusi streptozotocin bergantung jenis kelamin, tikus betina maupun tikus jantan menunjukkan bahwa kadar gula darah sama tinggi pada kedua jenis kelamin, sehingga tidak ada perbedaan yang signifikan pada kadar gula darah dari masing-masing jenis kelamin (Aseer et.al.,2015). Namun, pada penelitian lainnya menunjukkan penggunaan induksi streptozotocin pada kedua jenis kelamin, ditemukan adanya pengaruh perbedaan jenis kelamin pada hasil induksi karena kadar glukosa pada tikus jantan lebih tinggi dibandingkan tikus betina (Lorena et.al.,20I4). Penelitian sebelumnya menunjukkan hasil yang berbeda antara satu sama lain, hal ini membuat peneliti tertarik untuk melakukan Literatur review tentang hubungan jenis kelamin dan hewan coba terhadap sensitivitas induksi streptozotocin. Parameter yang akan dinilai pada penelitian literature review ini adalah faktor apa saja yang mempengaruhi jenis kelamin sehingga berpengaruh terhadap sensitivitas dari pemberian streptozotocin pada model hewan coba diabetes melitus. Penelitian ini diharapkan dapat memberikan informasi tentang peran jenis kelamin dan faktor-faktor yang mempengaruhi jenis kelamin terhadap sensitivitas dari streptozotocin dalam menghasilkan model hewan coba diabetes melitus sehingga bisa menjadi pertimbangan pemilihan jenis kelamin tikus yang digunakan dalam penelitian diabetes melitus.

\section{METODOLOGI}

\section{Desain Penelitian}

Desain penelitian menggunakan metode Literature review, dimana proses penelitiannya menggunakan metode pengumpulan data dari penelitian yang sudah pernah dilakukan yaitu dengan menggali dari berbagai kepustakaan seperti buku, jurnal ilmiah yang dipublikasi dari sumber terpercaya atau dokumen yang disimpan dan lain-lain.

\section{Sumber Data}

Penelitian ini menggunakan data sekunder. Data skunder adalah data yang di hasilkan bukan dari pengamatan langsung di lapangan namun diperoleh dari penelitian yang sudah dilakukan oleh peneliti-peneliti terdahulu tentang metode induksi streptozotocin dalam menghasilkan model hewan coba diabetes melitus. Sumber data sekunder yang dimaksud berupa 
buku, laporan ilmiah, jurnal yang berkenaan dengan metode induksi streptozotocin pada model hewan coba.

\section{Kriteria Pemilihan (Inklusi dan Ekslusi)}

Kriteria pemilihan terdiri dari kriteria inklusi dan kriteria eksklusi. Kriteria inklusi biasanya adalah karakteristik umum literatur atau data yang akan digunakan sedangkan kriteria eksklusi adalah literatur atau data yang tidak akan digunakan dalam penelitian literatur review dan akan dikeluarkan dari studi karena berbagai hal dan sebab.

I.) Kriteria Inklusi
a. Lama publikasi jurnal maksimal 10 tahun, dari rentang tahun 2010-2020.
b. Bahasa yang digunakan adalah Bahasa Indonesia atau Bahasa Inggris.
c. Tersedia full text.
d. Jurnal yang memiliki pembahasan mengenai faktor jenis kelamin yang mempengaruhi sensitivitas dari streptozotocin
e. Model hewan coba yang digunakan pada jurnal adalah tikus (Rattus) dan mencit (Mus musculus)

\section{2.) Kriteria Eklusi}
a. Jurnal memuat model hewan coba kelinci, monyet, anjing, dan kucing,
b. Jurnal membahas faktor lingkungan yang mempengaruhi sensitivitas streptozotocin
c. Jurnal tidak dapat diakses
d. Jurnal hanya menyediakan abstrak
e. Model hewan coba dengan diabetes melitus pada masa kehamilan (gestasional) dan diabetes melitus tipe lain.

\section{Proses Penelusuran Data}

Jurnal yang digunakan dalam literatur review didapatkan melalui metode pencarian jurnal dengan menggunakan electronic data base yaitu melalui NCBI, Wiley Online Library, Google Scholar, PubMed, Europe PMC, Portal
Garuda, ResearchGate dan DOAJ. Kata kunci yang digunakan dalam penelusuran data adalah "Sensitivitas induksi streptozotocin", "sensitivitas jenis kelamin terhadap STZ”, "Peran hormon terhadap induksi STZ” untuk jurnal nasional dan "Factors affecting streptozotocin sensitivity", "Role of gender differences in streptozotocin sensitivity" dan "Role of sex-hormone in streptozotocin induction sensitivity" untuk jurnal internasional dipilih full text dalam rentang waktu 2010 2020. Bersamaan dengan proses pengumpulan, dilakukan skrining sesuai dengan kriteria eksklusi dan kriteria inklusi pada jurnal ilmiah tersebut yang memiliki kesamaan topik. Jurnal yang telah masuk dan sesuai dengan kriteria inklusi kemudian di analisis kualitas datanya dengan Quality Assesment (QA). Telaah pustaka dilakukan untuk mendapatkan data yang dapat dipertanggung jawabkan keabsahan dan keakuratannya.

\section{Sintesis Data}

Sintesis data literatur review menggunakan metode naratif yaitu mengelompokkan data-data hasil literatur review demi menjawab tujuan dan pertanyaan penelitian. Jurnal penelitian dikumpulkan dan dipilih yang sesuai dengan kriteria inklusi peneliti, kemudian dilakukan ringkasan pada jurnal meliputi nama peneliti, tahun terbit jurnal, negara tempat dilakukannya penelitian, judul penelitian dan metode yang digunakan oleh peneliti serta hasil atau temuan yang didapatkan oleh peneliti. Hasil ringkasan jurnal dimasukkan ke dalam tabel yang sudah di susun sesuai alphabet dan sesuai tahun terbit dari jurnal.

\section{HASIL DAN PEMBAHASAN}

Pada Tabel I dibawah ini menunjukkan ringkasan terkait beberapa hasil sintesis data berdasarkan penggelompokkan jurnal nasional dan jurnal internasional yang telah memenuhi kriteria inklusi yang telah ditentukan. 
Egi Claudia Pratiwi, Elsa Trinovita, Agnes Immanuela Teomon. 2022. Literature Review: The Relationship Model Of Test Animal (Factors Of Gender And Hormones) On The Sensitivity Of The Induction Of Streptozotocin As An Agent Of Diabetogenic

Tabel I. Hasil Sintesis Data

\begin{tabular}{|c|c|c|c|}
\hline No. & Referensi & Metode Penelitian & Hasil Penelitian \\
\hline I. & Minji Choi et al, 2013 & $\begin{array}{l}\text { Penelitian menggunakan hewan coba jenis tikus } \\
\text { putih strain Sprague-Dawley dengan total } \\
\text { sampel } 48 \text { ekor tikus yang diberikan induksi } \\
\text { STZ } 50 \mathrm{mg} / \mathrm{kgBB} \text { melalui intravena. }\end{array}$ & $\begin{array}{l}\text { Kadar glukosa dan testosteron tikus } \\
\text { betina lebih tinggi secara signifikan } \\
\text { dibandingkan tikus jantan dan kadar } \\
\text { estrogen didapatkan sama. }\end{array}$ \\
\hline 2. & Imam et.al, 2012 & $\begin{array}{l}\text { Penelitian menggunakan hewan coba jenis tikus } \\
\text { putih strain Sprague-Dawley dengan total } \\
\text { sampel } 30 \text { ekor tikus yang diberikan induksi } \\
\text { STZ } 65 \mathrm{mg} / \mathrm{kgBB} \text { melalui intraperitoneal. }\end{array}$ & $\begin{array}{l}\text { Kadar glukosa darah pada tikus jantan } \\
\text { diabetes secara signifikan lebih tinggi } \\
\text { dibandingkan tikus betina diabetes. } \\
\text { Tikus jantan lebih rentan } \\
\text { dibandingkan tikus betina dalam } \\
\text { menghadapi induksi streptozotocin. }\end{array}$ \\
\hline 3. & Takenouchi et.al ,20I0 & $\begin{array}{l}\text { Penelitian menggunakan hewan coba jenis } \\
\text { mencit strain ICR yang diberikan induksi STZ } \\
200 \mathrm{mg} / \mathrm{kgBB} \text { melalui intravena. }\end{array}$ & $\begin{array}{l}\text { Kadar glukosa darah pada mencit } \\
\text { jantan dan mencit betina kelompok } \\
\text { perlakuan tidak ada perbedaan yang } \\
\text { signifikan. }\end{array}$ \\
\hline 4. & Aseer et.al, 2013 & $\begin{array}{l}\text { Penelitian menggunakan hewan coba jenis tikus } \\
\text { putih strain Sprague-Dawley dengan total } \\
\text { sampel } 48 \text { ekor tikus yang diberikan induksi } \\
\text { STZ } 50 \mathrm{mg} / \mathrm{kgBB} \text { melalui intravena. }\end{array}$ & $\begin{array}{l}\text { Kadar glukosa tikus betina lebih } \\
\text { rendah secara tidak signifikan } \\
\text { dibandingkan tikus jantan diabetes. } \\
\text { Kadar insulin plasma tikus betina } \\
\text { diabetes ditemukan lebih rendah } \\
\text { secara signifikan dibandingkan tikus } \\
\text { jantan diabetes. Kadar testosteron } \\
\text { ditemukan lebih tinggi secara } \\
\text { signifikan pada tikus betina } \\
\text { dibandingkan tikus jantan, dan } \\
\text { kadar estrogen ditemukan tidak } \\
\text { ada perbedaan signifikan. }\end{array}$ \\
\hline
\end{tabular}

\begin{tabular}{|c|c|c|c|}
\hline 5. & Chaudhari et.al, 2014 & $\begin{array}{l}\text { Penelitian menggunakan hewan coba jenis tikus } \\
\text { putih strain Sprague-Dawley dengan total } \\
\text { sampel } 48 \text { ekor tikus yang diberikan induksi } \\
\text { STZ } 50 \mathrm{mg} / \mathrm{kgBB} \text { melalui intravena. }\end{array}$ & $\begin{array}{l}\text { Kadar insulin plasma secara } \\
\text { signifikan lebih rendah pada tikus } \\
\text { betina diabetes dan kadar glukosa } \\
\text { darah lebih tinggi secara signifikan } \\
\text { pada tikus betina diabetes } \\
\text { dibandingkan tikus jantan diabetes. }\end{array}$ \\
\hline 6. & Virgen-Ortiz et.al ,2018 & $\begin{array}{l}\text { Penelitian menggunakan hewan coba jenis tikus } \\
\text { putih strain Sprague-Dawley dengan total } \\
\text { sampel } 32 \text { ekor tikus yang diberikan induksi } \\
\text { STZ } 60 \mathrm{mg} / \mathrm{kgBB} \text { melalui intravena. }\end{array}$ & $\begin{array}{l}\text { Kadar glukosa darah tikus betina } \\
\text { diabetes didapatkan lebih rendah } \\
\text { secara tidak signifikan dibandingkan } \\
\text { tikus jantan diabetes. }\end{array}$ \\
\hline 7. & Chaudhari et.al, 2015 & $\begin{array}{l}\text { Penelitian menggunakan hewan coba jenis tikus } \\
\text { putih strain Sprague-Dawley dengan total } \\
\text { sampel } 48 \text { ekor tikus yang diberikan induksi } \\
\text { STZ } 50 \mathrm{mg} / \mathrm{kgBB} \text { melalui intravena. }\end{array}$ & $\begin{array}{l}\text { Kadar glukosa darah tikus betina } \\
\text { dan tikus jantan diabetes } \\
\text { didapatkan tidak ada perbedaan } \\
\text { yang signifikan. Kadar plasma } \\
\text { insulin tikus betina diabetes } \\
\text { didapatkan lebih rendah secara }\end{array}$ \\
\hline
\end{tabular}


signifikan dibandingkan tikus jantan

diabetes.

\begin{tabular}{|c|c|c|c|}
\hline 8. & Sang-Hyun et.al.,20II & $\begin{array}{l}\text { Penelitian menggunakan hewan coba jenis tikus } \\
\text { putih strain Sprague-Dawley dengan total } \\
\text { sampel } 30 \text { ekor tikus yang diberikan induksi } \\
\text { STZ } 60 \mathrm{mg} / \mathrm{kgBB} \text { melalui intravena. }\end{array}$ & $\begin{array}{l}\text { Kadar glukosa darah tikus betina dan } \\
\text { tikus jantan diabetes didapatkan tidak } \\
\text { ada perbedaan yang signifikan. }\end{array}$ \\
\hline 9. & Witcher et.al.,20I0 & $\begin{array}{l}\text { Penelitian menggunakan hewan coba jenis tikus } \\
\text { putih strain Sprague-Dawley dengan total } \\
\text { sampel } 57 \text { ekor tikus yang diberikan induksi } \\
\text { STZ } 58 \mathrm{mg} / \mathrm{kgBB} \text { melalui intraperitoneal. }\end{array}$ & $\begin{array}{l}\text { Pada hasil penelitian didapatkan } \\
\text { bahwa kadar glukosa darah pada tikus } \\
\text { betina lebih tinggi secara signifikan } \\
\text { dibandingkan tikus jantan yang } \\
\text { diberikan perlakuan sama. }\end{array}$ \\
\hline 10. & Solleiro et.al.,2018 & $\begin{array}{l}\text { Penelitian menggunakan hewan coba jenis tikus } \\
\text { putih strain Wistar dengan total sampel } 84 \\
\text { ekor tikus yang diberikan induksi STZ } 50 \\
\text { mg/kgBB melalui intraperitoneal. }\end{array}$ & $\begin{array}{l}\text { Hasil penelitian didapatkan bahwa } \\
\text { ada perbedaan pada kadar glukosa } \\
\text { darah antara tikus jantan diabetes } \\
\text { dan tikus betina diabetes. Kadar } \\
\text { glukosa darah pada tikus jantan } \\
\text { diabetes lebih tinggi secara } \\
\text { signifikan jika dibandingkan tikus } \\
\text { betina dengan perlakuan sama. }\end{array}$ \\
\hline II. & Ariza et.al.,2014 & $\begin{array}{l}\text { Penelitian menggunakan hewan coba jenis } \\
\text { mencit strain ICR dengan total sampel } 40 \text { ekor } \\
\text { mencit yang diberikan induksi STZ } 40 \mathrm{mg} / \mathrm{kgBB} \\
\text { melalui intraperitoneal. }\end{array}$ & $\begin{array}{l}\text { Pengaruh perbedaan jenis kelamin } \\
\text { terlihat jelas pada efek yang } \\
\text { didapatkan setelah injeksi } \\
\text { streptozotocin, konsentrasi glukosa } \\
\text { darah mencit jantan lebih tinggi } \\
\text { secara signifikan jika dibandingkan } \\
\text { mencit betina yang diberikan } \\
\text { perlakuan sama. }\end{array}$ \\
\hline 12. & Aseer et.al., 2015 & $\begin{array}{l}\text { Penelitian menggunakan hewan coba jenis tikus } \\
\text { putih strain Sprague-Dawley dengan total } \\
\text { sampel } 48 \text { ekor tikus yang diberikan induksi } \\
\text { STZ } 50 \mathrm{mg} / \mathrm{kgBB} \text { melalui intravena. }\end{array}$ & $\begin{array}{l}\text { Nilai kadar glukosa darah pada tikus } \\
\text { jantan diabetes maupun tikus betina } \\
\text { diabetes didapatkan sama sehingga } \\
\text { tidak signifikan. Nilai insulin plasma } \\
\text { pada tikus betina diabetes didapatkan } \\
\text { lebih rendah secara signifikan } \\
\text { dibandingkan tikus jantan diabetes }\end{array}$ \\
\hline 13. & Boyoung et.al.,2020 & $\begin{array}{l}\text { Penelitian menggunakan hewan coba jenis } \\
\text { mencit strain C57BL/6] dengan total sampel } 40 \\
\text { ekor mencit yang diberikan induksi STZ } 40 \\
\text { mg/kgBB melalui intraperitoneal. }\end{array}$ & $\begin{array}{l}\text { Didapatkan bahwa kadar gula darah } \\
\text { puasa dan kadar HbAIC pada } \\
\text { kelompok jantan yang diinduksi } \\
\text { dengan streptozotocin secara } \\
\text { signifikan lebih tinggi dari kelompok } \\
\text { betina yang diberikan perlakuan } \\
\text { sama selama masa percobaan. }\end{array}$ \\
\hline
\end{tabular}

14. Zhang et.al.,2012 $\quad$ Penelitian menggunakan hewan coba jenis tikus Kadar glukosa darah tikus betina




\begin{tabular}{|c|c|c|}
\hline & $\begin{array}{l}\text { putih strain Sprague-Dawley yang diberikan } \\
\text { induksi STZ } 60 \mathrm{mg} / \mathrm{kgBB} \text { melalui intravena. }\end{array}$ & $\begin{array}{l}\text { diabetes didapatkan lebih tinggi secara } \\
\text { signifikan jika dibandingkan tikus } \\
\text { jantan diabetes. }\end{array}$ \\
\hline Jung-won et.al.,20I3 & $\begin{array}{l}\text { Penelitian menggunakan hewan coba jenis tikus } \\
\text { putih strain Sprague-Dawley dengan total } \\
\text { sampel } 48 \text { ekor tikus yang }\end{array}$ & $\begin{array}{l}\text { Kadar glukosa dan testosteron pada } \\
\text { tikus betina diabetes didapatkan lebih } \\
\text { tinggi secara signifikan jika } \\
\text { dibandingkan tikus jantan diabetes. } \\
\text { Kadar insulin plasma pada tikus }\end{array}$ \\
\hline & $\begin{array}{l}\text { diberikan induksi STZ } 50 \text { mg/kgBB melalui } \\
\text { intravena. }\end{array}$ & $\begin{array}{l}\text { betina diabetes didapatkan lebih } \\
\text { rendah secara signifikan jika } \\
\text { dibandingkan tikus jantan diabetes. } \\
\text { Kadar estrogen didapatkan sama. }\end{array}$ \\
\hline Ibias et.al.,2018 & $\begin{array}{l}\text { Penelitian menggunakan hewan coba jenis tikus } \\
\text { putih strain Sprague-Dawley dengan total } \\
\text { sampel I } 78 \text { ekor tikus yang diberikan induksi } \\
\text { STZ } 45 \mathrm{mg} / \mathrm{kgBB} \text { melalui intraperitoneal. }\end{array}$ & $\begin{array}{l}\text { Kadar glukosa darah pada tikus jantan } \\
\text { diabetes didapatkan lebih tinggi secara } \\
\text { signifikan jika dibandingkan tikus } \\
\text { betina. }\end{array}$ \\
\hline I7. Kataoka et.al.,2013 & $\begin{array}{l}\text { Penelitian menggunakan hewan coba jenis } \\
\text { mencit strain ICR yang diberikan induksi STZ } \\
50 \mathrm{mg} / \mathrm{kgBB} \text { melalui intraperitoneal. }\end{array}$ & $\begin{array}{l}\text { Kadar glukosa darah mencit betina } \\
\text { dan mencit jantan diabetes didapatkan } \\
\text { tidak ada perbedaan yang signifikan }\end{array}$ \\
\hline I8. Kintoko et.al., 2014 & $\begin{array}{l}\text { Penelitian menggunakan hewan coba jenis } \\
\text { mencit strain KM yang diberikan induksi STZ } \\
100 \mathrm{mg} / \mathrm{kgBB} \text { melalui intravena. }\end{array}$ & $\begin{array}{l}\text { Kadar glukosa darah mencit jantan } \\
\text { didapatkan lebih tinggi secara } \\
\text { signifikan dibandingkan mencit betina } \\
\text { hal ini berkaitan dengan adanya } \\
\text { estrogen yang berperan dominan } \\
\text { pada mencit betina }\end{array}$ \\
\hline
\end{tabular}

Diabetes melitus (DM) salah satu penyakit metabolik yang hingga saat ini menjadi masalah kesehatan di Indonesia bahkan di seluruh dunia. Diabetes melitus ditandai dengan hiperglikemia yang disebabkan oleh terjadinya gangguan pada pengeluaran insulin, kerja insulin atau keduanya. Pengujian agen antidiabetes dikembangkan menggunakan model hewan coba yang pada awal penelitian memiliki kadar glukosa yang normal, sehingga dibutuhkan agen diabetogenik untuk menyebabkan penyakit diabetes melitus pada hewan coba. Streptozotocin merupakan agen diabetogenik yang paling sering digunakan dalam penelitian diabetes melitus. Keberhasilan induksi streptozotocin salah satunya bergantung pada sensitivitas variabel streptozotocin. Beberapa faktor diketahui berperan dalam mempengaruhi sensitivitas dari streptozotocin yaitu strain, dosis pemberian, jalur pemberian, persiapan hewan coba dan jenis kelamin. Salah satu faktor yang mempengaruhi sensitivitas streptozotocin adalah jenis kelamin pada model hewan coba.

Tikus atau mencit jantan lebih rentan terhadap streptozotocin dibandingkan tikus atau mencit betina. Berdasarkan hasil penelitian didapatkan total 18 jurnal penelitian, I5 jurnal mendapatkan hasil signifikan antara jenis kelamin dengan sensitivitas induksi streptozotocin pada model hewan coba tikus maupun mencit dan 3 jurnal yang mendapatkan hasil yang tidak signifikan antara jenis kelamin dengan sensitivitas induksi streptozotocin. Berdasarkan hasil penelitian dari 18 jurnal penelitian, 8 jurnal mendapatkan hasil bahwa tikus atau mencit betina lebih rentan secara signifikan dibandingkan tikus atau mencit jantan diabetes dan 5 jurnal mendapatkan tikus atau mencit jantan secara signifikan lebih rentan dibandingkan tikus 
atau mencit betina terhadap induksi streptozotocin dan 4 hasil ditemukan tidak ada perbedaan signifikan. Adapun data hasil penelitian mengenai sensitivitas dapat dilihat pada Gambar I.

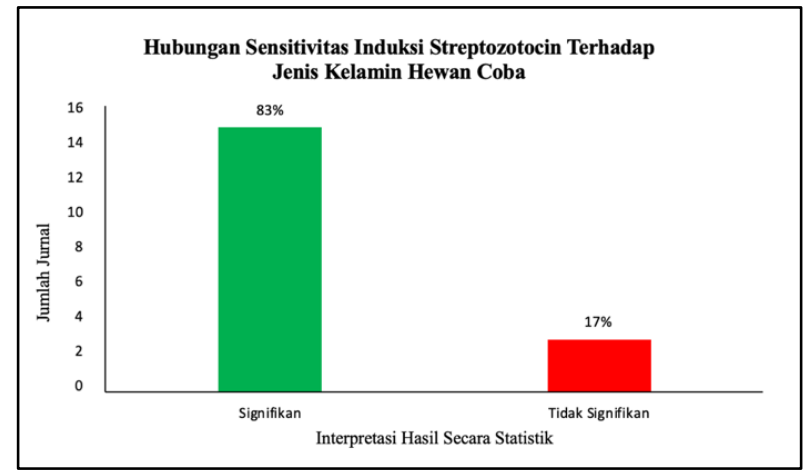

Gambar I. Hubungan Sensitivitas Induksi STZ dengan Jenis Kelamin Hewan Coba.

Pada beberapa penelitian didapatkan bahwa tikus atau mencit betina didapatkan cenderung lebih rentan terhadap induksi streptozotocin jika diberikan melalui jalur intravena dan tikus jantan lebih rentan terhadap induksi streptozotocin jika diberikan melalui jalur intraperitoneal. Berdasarkan hasil Literature review didapatkan dari total 18 jurnal, sebanyak 12 jurnal mendapatkan hasil signifikan bahwa jalur induksi mempengaruhi sensitivitas induksi streptozotocin berdasarkan jenis kelamin hewan coba dan 6 jurnal mendapatkan hasil yang tidak signifikan. Adapun hasil penelitian tentang hubungan jalur induksi streptozotocin dengan sensitivitas jenis kelamin dapat dilihat pada Gambar 2.

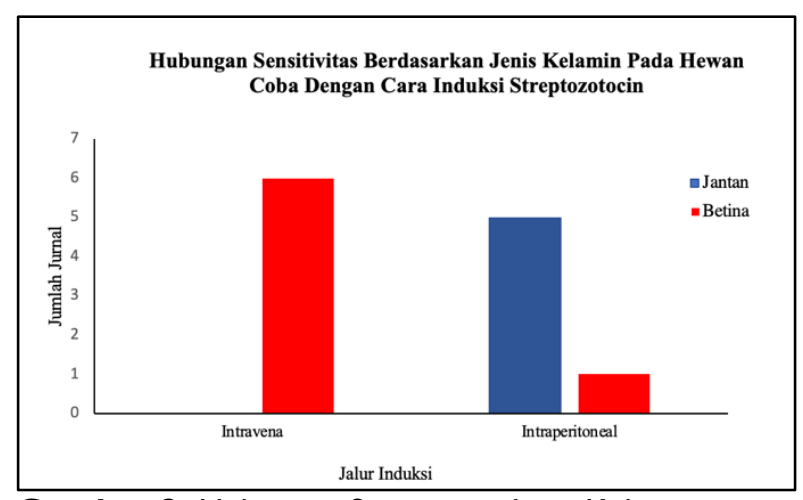

Gambar 2. Hubungan Sensitivitas Jenis Kelamin Dengan Jalur Induksi
Berdasarkan hasil 18 jurnal literatur review yang didapatkan, faktor hormon yang berperan dalam sensitivitas streptozotocin adalah estrogen, testosteron dan progesteron. Adapun jumlah presentase masing-masing dapat dilihat pada Gambar 3.

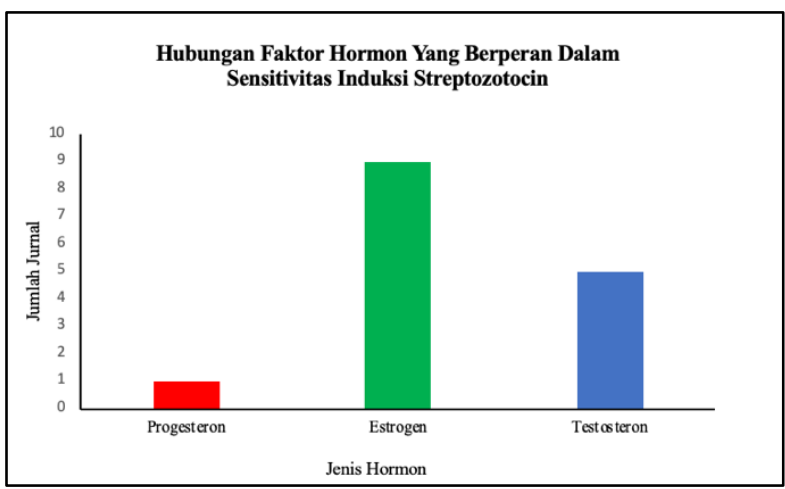

Gambar 3. Hormon Yang Berperan Dalam

Sensitivitas Induksi STZ

Hormon estrogen yang dimiliki hewan coba menjadi faktor yang diduga berperan dalam melindungi sel beta pankreas dari apoptosis oleh agen diabetogenik streptootocin yang menyebabkan defisiensi insulin. Pada diabetes melitus tipe I maupun diabetes melitus tipe 2, sitokin proinflamasi dan hiperglikemia menghasilkan stres oksidatif di pulau pankreas yang pada akhirnya menyebabkan terjadinya kematian sel (apoptosis). Pada model hewan coba tikus maupun mencit, didapatkan bahwa estrogen melindungi model hewan coba betina maupun jantan dari kematian sel dan hiperglikemia. Estrogen mengatur fungsi sel $\beta$ melalui estrogen reseptor dan sebagian besar estrogen memberikan sinyal melalui dua reseptor yaitu $E R \alpha$ dan ER $\beta$ melalui tiga jalur berbeda. Estradiol dibiosintesis oleh kompleks enzim sitokrom P450 yang disebut aromatase dan bekerja terutama melalui estrogen reseptor (ER) yaitu ER $\alpha$ dan ER $\beta$. Estrogen reseptor $\alpha$ (Era) diketahui menjadi dominan pada sebagian besar fungsi biologis dari estradiol (Tiano et.al., 20I2). Dalam neuron diketahui estradiol menekan apoptosis dan dianggap bahwa efek dari estrogen dimediasi terutama melalui estrogen reseptor (ER). Estrogen reseptor (ER) mendukung sekresi insulin, biosintesis dan melindungi pankreas dari rangsangan inflamasi pro- 
apoptosis yang disebabkan oleh diabetes melitus baik yang diinduksi dengan agen diabetogenik maupun tidak. Efek perlindungan ini kebanyakan dimediasi melalui estrogen reseptor ekstranuklear yang terletak di membran sitosol atau plasma. ER $\alpha$ melindungi sel $\beta$ dari stres oksidatif dan apoptosis yang diinduksi sitokin dengan menghambat aktivasi Caspase 3 melalui rapid actions. ER $\alpha$ memperkuat transkripsi gen insulin yang diinduksi glukosa dan sintesis insulin melalui jalur yang melibatkan Src, ERK dan NeuroDI. ER $\beta$ meningkatkan sekresi insulin yang distimulasi glukosa melalui penghambatan saluran $K_{A T P}$, dan ER menekan sintesis asam lemak dan melindungi terhadap lipotoksisitas dengan cara yang bergantung pada STAT3. Penelitian yang dilakukan oleh Joseph Tiano et.al (20I2) mendapatkan pada model tikus diabetes yang kekurangan insulin I7 $\beta$-estradiol (E2) melindungi sel $\beta$ pankreas penghasil insulin dari stres oksidatif, toksisitas dan apoptosis. Tiga reseptor estrogen (ERs)$\mathrm{ER} \alpha, \mathrm{ER} \beta$, and the $G$ protein-coupled estrogen receptors (GPER) teridentifikasi dihewan pengerat dan sel $\beta$ manusia. Reseptor estrogen memiliki fungsi masingmasing, saat aktivasi pada estrogen reseptor $\alpha(E R \alpha)$ akan meningkatkan kelangsungan sel $\beta$ pankreas, biosintesis insulin dan homeostasis lipid. Aktivasi estrogen reseptor $\beta$ (ER $\beta)$ meningkatkan sekresi insulin distimulasi glukosa dan aktivasi $G$ proteincoupled receptor ER (GPER) melindungi sel $\beta$ pankreas dari apoptosis serta meningkatkan sekresi insulin yang distimulasi glukosa dan homeostasis lipid. (Tiano et.al., 2012).

Hormon yang diketahui memiliki efek perlindungan terhadap pankreas selain estrogen adalah testosteron. Pada penelitian yang dilakukan oleh Martin Palomar et.al (2010) mendapatkan bahwa hormon testosteron mencegah apoptosis yang disebabkan oleh induksi agen diabetogenik streptozotocin. Testosteron menunjukkan perlindungan alami pada pankreas model hewan coba dan diketahui efek perlindungan ini dimediasi oleh reseptor androgen. Pada penelitian yang pernah dilakukan pada jaringan prostat, testosteron didapatkan berpartisipasi dalam mekanisme pertahanan stress oksidatif pada tikus dengan meningkatkan enzim antioksidan (Morales et.al.,20l0). Peneliti melakukan serangkaian percobaan menggunakan estradiol, progesteron dan testosteron dan didapatkan bahwa testosteron menunjukkan penurunan apoptosis yang signifikan pada tikus diabetes dibandingkan yang lainnya. Progesteron dan estradiol didapatkan tidak melindungi sel beta pankreas dari kerusakan yang disebabkan oleh streptozotocin dikarenakan tidak menunjukkan perlindungan yang signifikan jika dibandingkan dengan testosteron. Testosteron didapatkan tidak melindungi tikus betina dan hanya melindungi tikus jantan dari apoptosis yang disebabkan oleh streptozotocin. Tikus jantan didapatkan lebih resisten terhadap kerusakan sel yang disebabkan induksi streptozotocin dibandingkan tikus betina, hal ini dibuktikan dengan peningkatan signifikan apoptosis pada pulau langerhans pankreas pada kedua kelompok tikus betina dibandingkan dengan tikus jantan. Disisi lain didapatkan juga bahwa nilai insulin plasma tikus jantan lebih tinggi dibandingkan tikus betina meskipun tidak ada perbedaan yang signifikan antara keduanya. Perbedaan nilai ini berkaitan dengan pemberian hormon testosteron yang diketahui hanya melindungi sel beta pankreas pada tikus jantan namun tidak tikus betina, hingga menyebabkan apoptosis pada pulau langerhans pankreas pada tikus betina mengalami peningkatan yang lebih signifikan dibandingkan tikus jantan. Induksi streptozotocin diketahui menyebabkan proses apoptosis sebagai bentuk utama kematian pada sel $\beta$ pankreas baik pada diabetes melitus tipe I ataupun tipe 2. Mekanisme kematian sel melibatkan ILI $\beta$ dan nuklear factor (NF)-kB. Respon imun pada insulitis diabetes melitus tipe I menyebabkan dilepaskannya sitokin-sitokin inflamasi seperti IL-I $\beta$, TNF- $\alpha$, dan IFN- $\gamma$. Ketiganya menginduksi apoptosis sel $\beta$ melalui aktivasi jejaring gen sel $\beta$ dibawah kontrol faktor-faktor transkripsi seperti NF-kB dan STAT-I. 
Aktivasi NFkB memicu produksi Nitrit Oksida (NO), kemokin dan deplesi $\mathrm{Ca}^{2+}$ pada retikulum endoplasma. Hasil akhir kematian sel $\beta$ terjadi melalui aktivasi mitogen activated protein kinases (MAPK) yang memicu stress retikulum endoplasma dan pelepasan sinyal apoptosis oleh mitokondria. Apoptosis yang disebabkan oleh induksi streptozotocin akan menyebabkan kerusakan sel $\beta$ pankreas. Kerusakan sel $\beta$ pankreas akan menyebabkan turunnya produksi insulin sehingga tubuh tidak akan mampu mengubah glukosa menjadi energi yang disebarkan ke seluruh tubuh akibatnya akan terjadi penumpukan glukosa hingga mengakibatkan kadar glukosa darah meningkat (Morales et.al.,2010).

\section{KESIMPULAN}

Faktor hormon dari jenis kelamin yang mempengaruhi sensitivitas induksi streptozotocin adalah estrogen, testosteron dan progesteron. Pada hasil sintesis data didapatkan 15 artikel yang memuat pengaruh faktor hormon terhadap jenis kelamin, yaitu estrogen sebanyak 9 jurnal artikel, testosteron sebanyak 5 jurnal artikel dan progesteron sebanyak I jurnal artikel. Berdasarkan hasil sintesis data tentang hubungan sensitivitas induksi agen diabetogenik streptozotocin dengan jenis kelamin hewan coba didapatkan I5 artikel berhubungan dan 3 artikel tidak berhubungan. Sensitivitas jenis kelamin hewan coba terhadap induksi streptozotocin didapatkan sebanyak 4 jurnal menyatakan tikus atau mencit jantan lebih sensitif terhadap induksi streptozotocin, sebanyak 8 jurnal mendapatkan hasil tikus atau mencit betina yang lebih sensitif dan sebanyak 4 jurnal mendapatkan hasil yang tidak signifikan.

\section{REFERENSI}

I. World Health Organization (WHO). 2020. Diabetes melitus. https://www.who.int/healthtopics/diabetes\#tab=tab I

2. Setiati S, Alwi I, Sudoyo AW, Simadibrata M, Setiyohadi B, Syam AF. 2017. Buku Ajar Ilmu Penyakit Dalam jilid II. IV. Jakarta : InternaPublishing; p2325.

3. Husna F, Suyatna FD, Arozal W, Purwaningsih EH. 2019. Model Hewan Coba Pada Penelitian Diabetes. Pharmaceutical Sciences Research. 6(3): $|3|-4 \mid$.

4. Deeds MC, Anderson JM, Armstrong AS, Gastineau DA. 20II. Single Dose Streptozotocin Induced Diabetes: Considerations for Study Design in Islet Transplantation Models. Lab Anim. 45(3): pl31-140.

5. Aseer KR, Sangwoo WK, Myung-sook C, Yun JW. 2015. Opposite Expression of SPRAC between the Liver and Pancreas in Streptozotocin-Induced Diabetic Rats. Plos One.

6. Guyton AC, Hall JE. 20I4. Buku Ajar Fisiologi Kedokteran. Edisi 12. Jakarta : EGC.

7. Choi M, Choi J, Chaudhari H, Aseer K, Mukherjee R, Yun J. 2013. Gender-Dimorphic Regulation of Skeletal Muscle Proteins in StreptozotocinInduced Diabetic Rats. Cellular Physiology and Biochemistry. 3 I (2-3): 408-420.

8. Imam K, Sarwar M, Wali U, Siddique L, Perveen S. 2012. Gender and Contractile Functions of Slow and Fast Skeletal Muscles in Streptozotocin Induced Diabetic Sprague Dawley Rats. Romanian Journal of Diabetes Nutrition and Metabolic Diseases. 19(4): 4I7-424.

9. Takenouchi Y, Kobayashi T, Taguchi K, Matsumoto T, Kamata K. 2010. Gender Differences in Vascular Reactivity of Aortas from Streptozotocin-Induced Diabetic Mice. Biological \& Pharmaceutical Bulletin. 33(10): 1692-1697.

10. Aseer K, Yun J. 2013. Gender-dependent expression of pancreatic proteins in streptozotocin-induced diabetic rats. Biotechnology and Bioprocess Engineering. 18(6): I I22-II34. 
II. Chaudhari H, Yun J. 2014. Gender-dimorphic regulation of liver proteins in Streptozotocininduced diabetic rats. Biotechnology and Bioprocess Engineering. 19(1):93-107.

12. Virgen-Ortiz A, Alejandro Al, and Muñiz J. 2018. Gender-effect on the contractile properties of skeletal muscle in streptozotocin-induced diabetic rats. Journal of Musculoskeletal \& Neuronal Interactions. 18(2): p255.

13. Chaudhari H, Kim S, Yun J. 20I5. Genderdimorphic regulation of DJ I and its interactions with metabolic proteins in streptozotocin-induced diabetic rats. Journal of Cellular and Molecular Medicine. 19(5): 996-1009.

I4. Park S, Bahk J, Oh A, Gil N, Huh J, Lee J. 20 II. Gender difference and change of $\alpha \mathrm{l}$ adrenoceptors in the distal mesenteric arteries of streptozotocin-induced diabetic rats. Korean Journal of Anesthesiology. 6I(5): 4I9.

15. Witcher D, Sakai N, Williams B, Rahimian R, Anderson L. 2010. Gender differences in the effects of streptozotocin-induced diabetes on parasympathetic vasodilatation in the rat submandibular gland. Archives of Oral Biology. 55(I0): 745-753.

16. Rebolledo-Solleiro D, Fernández-Guasti A. 2018. Influence of sex and estrous cycle on blood glucose levels, body weight gain, and depressivelike behavior in streptozotocin-induced diabetic rats. Physiology \& Behavior. 194: 560-567.

17. Ariza L, Zaguirre M, García M, Blasco E, Rabanal $R$, Bosch A et al. 2014. Hyperglycemia and hepatic tumors in ICR mice neonatally injected with streptozotocin. Lab Animal. 43(7): 242-249.

18. Aseer K, Kim S, Choi M, Yun J. 2015. Opposite Expression of SPARC between the Liver and Pancreas in Streptozotocin-Induced Diabetic Rats. PLOS ONE. 10(6).

19. Kim B, Kim Y, Nguyen P, Nam H, Suh J. 2020. Sex differences in glucose metabolism of streptozotocin-induced diabetes inbred mice (C57BL/6J). Applied Biological Chemistry. 63(I).
20. Zhang R, Thor D, Han X, Anderson L, Rahimian R. 20I2. Sex differences in mesenteric endothelial function of streptozotocin-induced diabetic rats: a shift in the relative importance of EDRFs. American Journal of Physiology-Heart and Circulatory Physiology. 303(10): pl I83-98.

2I. Choi JW, Aseer KR, Chaudhari HN, Mukherjee R, Choi M, Yun JW. 2013. Gender dimorphism in regulation of plasma proteins in streptozotocininduced diabetic rats. Proteomics. 13(16): p248294.

22. Íbias J, O'Dell LE, Nazarian A. 2018. Insulin dependent and independent normalization of blood glucose levels reduces the enhanced rewarding effects of nicotine in a rodent model of diabetes. Behav Brain Res. 351:p75-82.

23. Kataoka, M., Kawamuro, Y., Shiraki, N., Miki, R., Sakano, D., Yoshida, T., Yasukawa, T., Kume, K., \& Kume, S. 2013. Recovery from diabetes in neonatal mice after a low-dose streptozotocin treatment. Biochemical and biophysical research communications. 430 (3):p I I 03-08.

24. Kintoko K, Wen Q, Lin X, Zheng N. 2014. Diabetogenic Activity of Streptozotocin on Kunming Strain Mice as Animal Model of Diabetes Mellitus. Pharmacy and Biological Sciences. 9(I):P48-53.

25. Tiano J.P, Mauvais-Jarvis F. 20I4. Importance of oestrogen receptors to preserve functional $\beta$-cell mass in diabetes. Nat. Rev. Endocrinol. 4: p342-5I

26. Morales MP, Marimoto S, Mendoza-Rodriguez CA, Cerbon MA. 20I0. The Protective Effect of Testosterone on Streptozotocin-Induced Apoptosis in $\beta$-Cells is Sex Specific. Pancreasjournal. 39(2): pl0 